\title{
Modeling and quantification of cancer cell invasion through collagen type I matrices
}

\author{
OLIVIER DE WEVER ${ }^{*, 1}$, AN HENDRIX $\#, 2$, ASTRID DE BOECK\#,1, WENDY WESTBROEK 4 , \\ GEERT BRAEMS ${ }^{3}$, SHAHIN EMAMI ${ }^{5,6}$, MICHĖLE SABBAH ${ }^{5}$, CHRISTIAN GESPACH $^{5,6}$, and MARC BRACKE ${ }^{1}$ \\ ${ }^{1}$ Laboratory of Experimental Cancer Research, Department of Radiotherapy and Nuclear Medicine, ${ }^{2}$ Department of \\ Medical Oncology, and ${ }^{3}$ Department of Gynaecology, Ghent University Hospital, Gent, Belgium, ${ }^{4}$ National Human

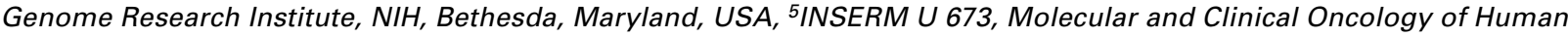 \\ Solid Tumors, ${ }^{6}$ INSERM U938 and Université Pierre et Marie Curie-Paris, Faculté de Médecine, Paris, France
}

\begin{abstract}
Tumor invasion is the outcome of a complex interplay between cancer cells and the stromal environment. Considering the contribution of the stromal environment, we developed a membrane-free single-cell and spheroid based complementary model to study cancer invasion through native collagen type-I matrices. Cell morphology is preserved during the assays allowing real time monitoring of invasion-induced changes in cell structure and F-actin organization. Combining these models with computerized quantification permits the calculation of highly reproducible and operator-independent data. These assays are versatile in the use of fluorescent probes and have a flexible kinetic endpoint. Once the optimal experimental conditions are empirically determined, the collagen type-I invasion assays can be used for preclinical validation of small-molecule inhibitors targeting invasion. Initiation and monitoring of the single-cell and spheroid invasion model can be achieved in $8 \mathrm{~h}$ (over 3 days) and in $14 \mathrm{~h}$ (over 8 days) respectively.
\end{abstract}

KEY WORDS: invasion, collagen, stroma, 3D matrices, ecosystem

\section{Introduction}

Emergence of the invasive behavior during cancer progression is a critical feature of malignancy. Several classes of proteins involved in the tethering of cells to their surroundings in a tissue are altered in cells possessing invasive capabilities. The affected proteins include cell-cell adhesion molecules such as members of the calcium-dependent cadherin families, and integrins, which link cells to extracellular matrix substrates. However, molecular and cellular research focused on cancer cells themselves appear to be inadequate since several tumor cell populations including myofibroblasts, bone marrow-derived mesenchymal stem cells, immune and endothelial cells become resident within clinical tumors (De Wever et al., 2007; De Wever et al., 2008). Indeed, according to the multifactorial nature of the malignant transformation, it is generally well accepted that cancer invasion is the outcome of a complex interplay between cancer cells and the host tissue environment in solid tumors (Hanahan and Weinberg, 2000). In vitro modeling is appropriate for dissecting various mechanisms involved in cancer cell invasion and stromal cell infiltration because it can simultaneously and quantitatively integrate the complex interactions between multiple factors and tumor cell populations (De Wever et al., 2004b; Nyström et al., 2005). To study this cell-matrix interaction in vitro, several natural extracellular matrix (ECM) types have initially been applied. Bone (Kuettner et al., 1978), salt-extracted cartilage (Pauli et al., 1981) and amnion membrane (Liotta et al., 1980) are examples of devitalized substrata that have been launched in the past to discriminate between invasive and non-invasive cells. Lack of homogeneity of these substrata often made interpretation of invasion difficult, and hampered the reproducibility of those assays. To overcome these drawbacks reconstituted and hence more homogeneous ECMs were developed, and proposed as substrata to test invasion. Currently, Matrigel (Albini et al., 2007), Humatrix (Kedeshian et al., 1998) and pepsin-extracted or native, acid-extracted collagen type I (Sabeh et al., 2009; Vakaet et al.,

Abbreviations used in this paper: ECM, extracellular matrix; GFP, green fluorescent protein.

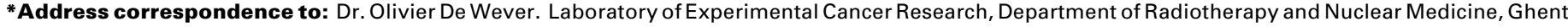
University Hospital, De Pintelaan 185, B-9000 Gent, Belgium. Tel: +32-9-332-3008. Fax: +32-9-332-4991. e-mail: olivier.dewever@UGent.be
}

\#Note: Both authors contributed equally to this work. 
1991; Wolf et al., 2003) are frequently used as ECM substrates in invasion assays. The ideal model would allow for easy manipulation, quantification by digital analysis, morphotypic and morphometric studies, further downstream biochemical assays, and close recapitulation of the in vivo situation (Bruyère et al., 2008).

The models presented in the present protocol, are based on the preparation of a native collagen type I gel, the main interstitial matrix component in solid tumors, in which the addition of test cell populations either as single-cells on top of the collagen or as cellular spheroid aggregates inside the collagen is varied. The use of multicellular spheroid aggregates allow us to gain insight into therapeutic problems associated with metabolic and proliferative gradients, such as the altered responsiveness and effects of chronically hypoxic tumor cells, and the importance of 3D cellcell and cell-matrix interactions in radio-and chemoresistance (Friedrich et al., 2009). With the increasingly recognized fact that gene signatures from the stromal environment are critical parameters for tumor progression and clinical outcome (Finak et al., 2008), we need to develop original models to test how stromalderived structural and biochemical cues drive invasive cancer growth. In the heterotypic spheroid invasion model, the tumor environment is represented by stromal myofibroblasts. During the time course of the assay cell morphology is preserved in the matrix, allowing biochemical analysis and real-time monitoring to acquire important insights into basic features of the invasive migratory process. In a next step, computer-generated binary images allow the calculation of highly reproducible and operatorindependent data, such as the invasion area and morphometry. This protocol or parts of this protocol have been used successfully by us and others in the past (Behrens et al., 1993; De Wever et al., 2004a;2004b; Fritah etal., 2008; Grijelmo etal., 2007; Meerschaert etal., 2007; Mooradian etal., 1992; Nguyen et al., 2005; Nyström etal., 2005; Roperch etal., 2008; Van Aken etal., 2004; Vleminckx et al., 1991). Although it may be impossible to achieve a general standardization of collagen type I invasion models and analysis for all experimental settings, the easy-handling protocols presented herein for single cell and spheroid invasion models, and morphometric analysis are designed to encourage scientists and the pharmaceutical industry to consider (collagen type I) invasion models as part of the standard repertoire for drug evaluation.

\section{Experimental Protocols (I - Reagents, Equipment)}

\section{Reagents}

The lists provided in this section are based on the materials used in our laboratory. Chemicals and cell culture materials may be purchased from other distributors and/or manufacturers.

- Dulbecco's modified eagle medium (DMEM; Invitrogen cat.no. 41965-039). Store at $4^{\circ} \mathrm{C}$

- FBS (Greiner cat.no. 758093S5595)

Long time storage at $-20^{\circ} \mathrm{C}$, short term at $4^{\circ} \mathrm{C}$.

CRITICAL: Serum quality affects single-cell and spheroid formation and should be routinely tested!

- Penicillin/streptomycin 10,000 U pen./10mg strep. $\mathrm{ml}^{-1}$ (Invitrogen cat.no. 15140163$)$. Store at $4^{\circ} \mathrm{C}$.

- Trypsin (0.5\% wt/vol) ethylenediaminetetraacetic acid (EDTA; $0.2 \% \mathrm{wt} / \mathrm{vol}$ ) solution (Invitrogen cat.no. $25300054-100 \mathrm{ml}$ ). Store at $4^{\circ} \mathrm{C}$.

- Phosphate-buffered saline (PBS; Invitrogen cat.no. 20012019).
Store at $4^{\circ} \mathrm{C}$.

- Trypan blue (Sigma cat.no. T8154)

CAUTION: Trypan blue is a possible cancer hazard: wear gloves.

- Native, acid-extracted rat tail collagen type I (BD Biosciences cat.no. 354236). Store at $4^{\circ} \mathrm{C}$.

- Calcium- and magnesium-free Hank's balanced salt solution 1x (CMF-HBSS; Sigma cat.no. H6648). Store at $4^{\circ} \mathrm{C}$.

- Minimal essential medium (MEM), concentrated 10-fold. (Invitrogen cat.no. $21430-20)$. Store at $4^{\circ} \mathrm{C}$.

- Sodium bicarbonate (Sigma cat.no. S5761)

- Sodium hydroxide (Sigma cat.no. S5881)

CAUTION: Corrosive, wear suitable gloves and eye/face protection.

- Melting ice

- Human recombinant transforming growth factor (TGF)- $\alpha$ (Sigma cat.no. T7924). Store at $-20^{\circ} \mathrm{C}$.

- Dimethyl sulfoxide (DMSO; Sigma cat.no. D8418).

CAUTION: Hazardous: avoid contact with skin and eyes.

- Gefitinib (kindly provided by AstraZeneca). Store at $-20^{\circ} \mathrm{C}$.

- Paraformaldehyde (Fluka cat.no. 76240)

- Phosphate-buffered saline with $\mathrm{Ca}^{2}+, \mathrm{Mg}^{2+}\left(\mathrm{PBS}^{\mathrm{D}}\right.$-Dulbecco's modification-; Invitrogen cat.no. 14040083). Store at $4^{\circ} \mathrm{C}$.

- BSA (Sigma cat.no. A4503-500g). Store at $4^{\circ} \mathrm{C}$.

- Glycine (Sigma cat.no. G6201)

- Triton X-100 (Biorad cat.no. 161-0407)

- Phalloidin Alexa Fluor 488 and Alexa Fluor 594 (Molecular Probes cat.no. A12379 and A12381). Store at $4^{\circ} \mathrm{C}$.

- Mounting medium (Glycergel; DakoCytomation cat.no. C0563)

- Microscope slides and cover glass (Immuno-Cell; cat.no. 7107 and 1818)

\section{Equipment}

- Bürker hemocytometer

- Cell culture plates (6 well multidish plate) (Nunc cat.no. 140675)

- Cell culture flasks T25 and T75 (Greiner Bio-One GmbH cat. nos. 690175 and 658175)

- Centrifuge: Sorvall RT 6000D

- $\mathrm{CO}_{2}$ incubators (Life Sciences international, Forma Scientific 3111)

- Erlenmeyer (Sigma cat.no. Z723045)

- Gyrotory shaker (New Brunswick Scientific Company cat.no. G-33)

- Microscopes: Inverted phase-contrast microscope equipped with a digital colour camera (Leica Microsystems GmbH cat. nos. DMI 3000B and DFC $340 \mathrm{FX}$ ). Fluorescence/phase-contrast motorized inverted Axiovert 200M microscope equipped with an AxioCam HRm camera (Carl Zeiss Microlmaging GmbH cat. no. 426511-9901-000) and a temperature controlled $\mathrm{CO}_{2}$ incubation system for live cell time-lapse experiments.

Zeiss 510 META confocal laser-scanning microscope using a 488 argon and a $543 \mathrm{HeNe}$ laser. Images are acquired using a Plan Apochromat $20 \mathrm{X} / 0.75$ or a Plan NeoFluar $40 \mathrm{X} / 1$ lens.

-Scalpel and forceps to manage fixed collagen gels

-Software: Axiovision 4.5 (Zeiss); image manager (IM50; Leica); Image $\mathrm{J}$ (http://rsbweb.nih.gov/ij/); statistical analysis (SPSS)

\section{Reagent setup}

\section{Standard medium}

DMEM with phenol red containing $4.5 \mathrm{~g} \mathrm{liter}^{-1} \mathrm{D}$-glucose, $1 \%$ (wt/ vol) L-glutamine and without sodium pyruvate, supplemented with $100 \mathrm{U} \mathrm{ml}^{-1}$ penicillin, $100 \mathrm{mg} \mathrm{ml}^{-1}$ streptomycin and $10 \% \mathrm{FBS}$ is used 
as standard medium for routine cell and spheroid culturing and preparation of collagen gels. Standard medium can be stored at $4^{\circ} \mathrm{C}$ for up to 2 weeks.

\section{Drugs for preclinical validation (e.g. gefitinib)}

Prepare appropriate stock solutions of drugs and store at conditions required to keep optimal drug activity. For most but not all drugs in our laboratory, $100 \mathrm{mM}$ stock solutions in DMSO and storage at $20^{\circ} \mathrm{C}$ are suitable. Final DMSO concentrations in the collagen invasion assays of $<0.2 \%$ are not expected to affect cancer invasion. Minor effects may already be seen at a concentration of $0.2-1 \%$, depending on the cell type and culture condition. A proportion of $>1 \%$ DMSO in the drug dilution for treatment should be avoided. Other solvents are to be verified. Individual solvent controls for each drug concentration may be considered.

\section{$0.25 M$ Sodium bicarbonate}

Dissolve $2.2 \mathrm{~g}$ of sodium bicarbonate in $100 \mathrm{ml}$ of CMF-HBSS. Stir until the solution becomes clear, store at $4^{\circ} \mathrm{C}$.

\section{$1 M$ Sodium hydroxide}

Dissolve $4 \mathrm{~g}$ of sodium hydroxide in $100 \mathrm{ml}$ of CMF-HBSS. Stir until the solution becomes clear, store at $4^{\circ} \mathrm{C}$.

\section{Human recombinant TGF- $\alpha$}

Add $1 \mathrm{ml}$ of sterile PBS containing $0.1 \% B S A$ to a vial containing $0.1 \mathrm{mg}$ of TGF- $\alpha$. This makes a a stock solution of $100 \mu \mathrm{g} \mathrm{ml}^{-1}$. Prepare $50 \mu \mathrm{l}$ aliquots and store at $-20^{\circ} \mathrm{C}$ for up to 6 months.

\section{$3 \%$ paraformaldehyde}

Dissolve $3 \mathrm{~g}$ of paraformaldehyde in PBS and adjust the volume to $100 \mathrm{ml}$ of $\mathrm{PBS}$, heat the mixture to $80^{\circ} \mathrm{C}$, stir until the solution becomes clear, add $10 \mu \mathrm{l} 1 \mathrm{MCaCl}_{2}$ and $10 \mu \mathrm{l} 1 \mathrm{M} \mathrm{MgCl}_{2}$ and cool to room temperature and check that the $\mathrm{pH}=7.4$. Filter through a $0.45 \mu \mathrm{m}$ filter and use immediately or store aliquots in dark glass bottles in $-20^{\circ} \mathrm{C}$. Thawed paraformaldehyde should be warmed to at least room temperature or preferable $37^{\circ} \mathrm{C}$, discard remaining solution after thawing.

CAUTION Paraformaldehyde is toxic. Work under the hood and use gloves.

\section{$2 \% B S A / 1 \% g / y$ cine in PBS}

Dissolve $2 \mathrm{~g}$ BSA and $1 \mathrm{~g}$ glycine in PBS and adjust the volume to $100 \mathrm{ml}$ of PBS, stir until the solution becomes clear, store at $4^{\circ} \mathrm{C}$.

\section{$0.5 \%$ Triton $X-100$ solution \\ Add $500 \mu$ l of Triton $X-100$ to $100 \mathrm{ml}$ of PBS.}

\section{Experimental Protocols (II - Equipment Setup)}

\section{Cancer cell lines}

Various cancer cell lines of different origin are subjected to the collagen invasion protocol (Table 1). All of these lines are commercially available (except HCT-8/E11 which is an epithelial subclone from HCT-8 (Vermeulen et al., 1995); the HCT-8/E11 cell line is available from our laboratory upon request). Not all of these can be applied in a spheroid-based screen (Friedrich et al., 2009). All cell lines are cultured in standard medium and transferred using the same trypsin/EDTA working solution. All stocks have been tested to be free of mycoplasms, are frozen in $90 \%$ FBS plus $10 \%$ (vol/vol) DMSO solution and are stored in liquid nitrogen for subsequent reculturing. Cancer cells between passages $>2$ and $<30$ are most suitable for use in single-cell and spheroid invasion model. Keep cultures in humidified atmosphere with $10 \% \mathrm{CO}_{2}$ in air at $37^{\circ} \mathrm{C}$.

\section{Stromal myofibroblast primary cultures}

Isolate primary human colon tumor-derived myofibroblast cells from tumor explants (De Wever et al., 2004a; 2004b). Myofibroblasts at passages $>2$ and $<8$ are most suitable for use in the heterotypic spheroid invasion model. Use standard medium for routine culturing. Keep cultures in humidified atmosphere with $10 \% \mathrm{CO}_{2}$ in air at $37^{\circ} \mathrm{C}$.

\section{Image processing}

Sample preparation, optical microscopy observations and image caption conditions must be carefully established in order to achieve optimal image quality, i.e., a maximum contrast between the sample and the background. However, in some cases, experimental conditions prevent, to fulfill completely this requirement. For example, if the single-cells or spheroids are placed at the border of the support, uneven illumination could generate a dark rim on both sides of the image.

Process and quantify the digital images (300 pixels inch ${ }^{-1}$ ) using ImageJ software. Change the image to 8-bit type. Use the threshold function to convert areas of interest to saturated black areas in a uniform manner to have a binary (black\&white) image. In a next step, subject the binary image to two 'clean-up' procedures: exclude all particles less than three pixels in size and remove any artifacts by comparing the binary image to the phasecontrast or phase-contrast-GFP fluorescence pictures. Use the set measurements dialog box to specify area and perimeter. Use the analyze particle dialog box to measure all particles and to generate a "particle report" for each image in which the area and perimeter of individual particles and the area of the sum of individual particles is documented. The area calculated as number of pixels is defined as invasion-area in the single-cell invasion

TABLE 1

\section{MORPHOTYPE ANALYSIS OF TISSUE CULTURE PLASTIC SUBSTRATE AND SINGLE CELL INVASION INTO COLLAGEN TYPE I OF 15 COMMERCIALLY AVAILABLE HUMAN CANCER CELL LINES}

\begin{tabular}{|c|c|c|c|c|}
\hline Tumor entity & Cell line & ATCC number & Morphotype & Invasion \\
\hline Breast & $\begin{array}{c}\text { MCF7 } \\
\text { MDA-MB-231 } \\
\text { T-47D } \\
\text { ZR-75-1 }\end{array}$ & $\begin{array}{l}\text { HTB-22 } \\
\text { HTB-26 } \\
\text { HTB-133 } \\
\text { CRL-1500 }\end{array}$ & $\begin{array}{l}E \\
F \\
E \\
E\end{array}$ & $\begin{array}{c}- \\
++ \\
- \\
-\end{array}$ \\
\hline Cervix & HeLa & CCL-2 & $\mathrm{F}$ & +++ \\
\hline Colon & $\begin{array}{l}\text { HCT-8/E11 } \\
\text { HCT } 116 \\
\text { HT-29 } \\
\text { LoVo } \\
\text { SW480 }\end{array}$ & $\begin{array}{l}\text { Derived from CCL-244 } \\
\text { CCL-247 } \\
\text { HTB-38 } \\
\text { CCL-229 } \\
\text { CCL-228 }\end{array}$ & $\begin{array}{l}E \\
E \\
E \\
E \\
M\end{array}$ & $\begin{array}{l}- \\
- \\
- \\
-\end{array}$ \\
\hline Neuroblastoma & SK-N-SH & HTB-11 & $\mathrm{F}$ & +++ \\
\hline Osteosarcoma & HT-1080 & CCL-121 & $\mathrm{F}$ & +++ \\
\hline Ovary & SK-OV-3 & HTB-77 & $\mathrm{F}$ & ++ \\
\hline Prostate & $\begin{array}{l}\text { DU } 145 \\
\text { PC3 }\end{array}$ & $\begin{array}{l}\text { HTB-81 } \\
\text { CRL-1435 }\end{array}$ & $\begin{array}{l}E \\
F\end{array}$ & $\begin{array}{c}- \\
+++\end{array}$ \\
\hline
\end{tabular}

E, epitheloid; F, fibroblastic; M, Mixed; -, 0-4.9\%; +, 5-9.9\%; ++, 10-14,9\%; +++, >15\% 
assay and as area in the heterotypic spheroid invasion assay. The mean invasion area or area is indicated +/- standard error mean. The shape factor refers to a value that is affected by an object's shape but is independent of its dimensions. Calculate the factor shape from Image $\mathrm{J}$ binarized $\mathrm{F}$-actin stainings using the following formula (perimeter) ${ }^{2} / 4 \pi$ (area) where perimeter $=2 \pi R$ and area $=\pi R^{2}$. It gives a minimal value of 1 for a perfect circle and larger values for shapes having a higher ratio of perimeter to area (Pinner and Sahai, 2008). The mean factor shape of 30 singlecells or 20 spheroids is indicated +/- standard error mean. The percent fragmentation, used in the heterotypic spheroid invasion model, is calculated as the percent of single or clustered cells released from the total spheroid area. The mean percent fragmentation of 20 spheroids is indicated +/- standard error mean.

\section{Statistics}

Perform Chi-Square test for group comparison in the singlecell collagen invasion model when counting the number of noninvasive and invasive cells in 10 microscopic fields.

Use Mann Whitney test when comparing invasion area in the single cell collagen invasion model and factor shape in both invasion models.

Analyze the area data in the heterotypic spheroid collagen invasion model by repeated measures analysis of variance with testing of the equality of variances. Use the Tukey's test for post hoc contrasts.

\section{Experimental Protocols (III - Procedure)}

\section{Single-cell collagen invasion model}

For schematic see Fig. 1.

Preparation of a collagen gel: Working time 30min, incubation time at least $1 \mathrm{~h}$

1) Prepare collagen type I solution with a final concentration of $1 \mathrm{mg} \mathrm{ml}^{-1}$ collagen type I by mixing the following precooled (stored at $4{ }^{\circ} \mathrm{C}$ ) components: 4 volumes collagen type I (stock is $3.49 \mathrm{mg}$ $\mathrm{ml}^{-1}$ ), 5 volumes of CMF-HBSS, 1 volume of MEM (10x), 1 volume of $0.25 \mathrm{M} \mathrm{NaHCO} 3,2.65$ volumes of standard medium and 0.3 volumes of $1 \mathrm{M} \mathrm{NaOH}$ to make the solution alkaline.

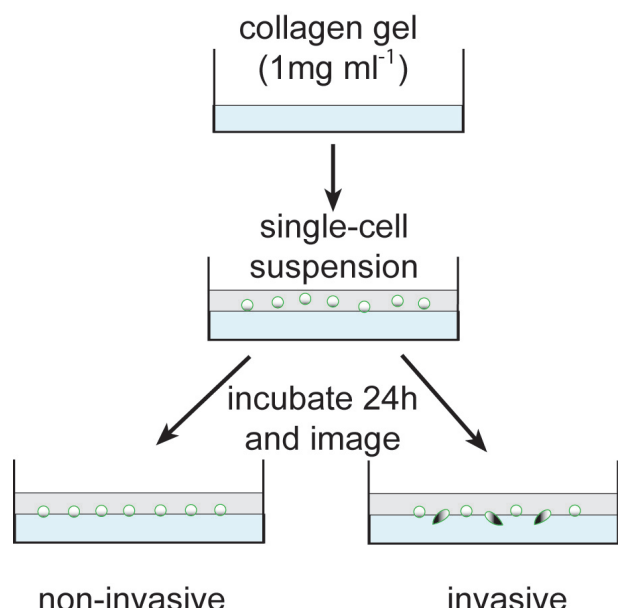

Fig. 1. Schematic of the single-cell invasion model.
CRITICAL: Mix gently by pipetting, avoiding the introduction of air bubbles. Keep the solution on melting ice. The final solution should look purple due to the phenol red $\mathrm{pH}$ indicator showing a $\mathrm{pH}>9$. The concentration of the stock collagen type I is variable. Adapt volume of collagen type I with CMF-HBSS if necessary. Volume of MEM, $\mathrm{NaHCO}$, standard medium and $\mathrm{NaOH}$ remain constant. If necessary, you may increase concentration of collagen type I up to $2 \mathrm{mg} \mathrm{ml}^{-1}$.

TIMING: Collagen type I solution can be stored at $4^{\circ} \mathrm{C}$ for up to two weeks.

TROUBLESHOOTING advice can be found in Table 2 .

2) Add, for each test-condition, $1.25 \mathrm{ml}$ of collagen type I solution to one well of a 6-well plate, spread homogeneously and let gelify on a flat surface in a humidified atmosphere of $10 \% \mathrm{CO}_{2}$ in air at $37^{\circ} \mathrm{C}$ for at least $1 \mathrm{~h}$ to obtain a collagen gel with a $250 \mu \mathrm{m}$ central thickness in the well.

CRITICAL: Avoid introduction of air bubbles. Monitor the polymerization of the collagen gel carefully before starting step 5-6.

TIMING: You may keep collagen type I gels up to $24 \mathrm{~h}$ in a humidified atmosphere of $10 \% \mathrm{CO}_{2}$ in air at $37^{\circ} \mathrm{C}$.

SUGGESTION: You may add the testing products in collagen type I solution.

TROUBLESHOOTING advice can be found in Table 2.

\section{Preparation of single-cells: Working time 30min}

Perform step 3-5 during gelification time of collagen.

3) Prepare a single-cell suspension in standard medium by mild enzymatic dissociation, using a $\mathrm{Ca}^{2+}$ - and $\mathrm{Mg}^{2+}$-free PBS wash followed by incubation with a trypsin/EDTA solution, of an exponentially growing culture (usually $70 \%$ confluence is used). CRITICAL: Optimize trypsinization procedure for every cell type. It is essential to inactivate trypsin and to remove EDTA after trypsin/EDTA procedure. Trypsin inhibition is accomplished by trypsin inhibitors in the serum in the standard medium. Therefore, dilute the suspended cells with $5 \mathrm{ml}$ of standard medium and pellet by centrifugation. Aspirate the supernatant, and resuspend the cells in $5 \mathrm{ml}$ of standard medium. Repeat this procedure twice. Avoid cell doublets and clusters by filtering the cell suspensions through 30-35 $\mu \mathrm{m}$ sterile meshes or fine needle aspiration (especially when using strongly adherent cell lines such as HCT-8/E11, MCF7 and HT-29). Avoid repeated dissociation of cell cultures within less than $2 \mathrm{~d}$.

4) Count a small aliquot of the cell suspension after staining with Trypan blue (0.04\% Trypan blue in PBS) to exclude dead cells.

Initiation of invasion model: Working time 30 min for 6 conditions

5) Prepare 1-2 $\times 10^{5}$ viable, single-cells in $1 \mathrm{ml}$ standard medium in $15 \mathrm{ml}$ polypropylene tubes. Add test products such as growth factors (TGF- $\alpha$ ) or drugs for preclinical (gefitinib) validation in desired concentration. Gently seed this mixture on top of blindcoded collagen type I gels.

CRITICAL: Avoid high pressure seeding of the cell suspension, it may damage the collagen gel.

Use left-right and forward-backward movement of the 6-well plate to make sure the cells are evenly distributed over the whole gel surface.

TROUBLESHOOTING advice can be found in Table 2 .

6) Incubate cells in a humidified atmosphere with $10 \% \mathrm{CO}_{2}$ in 
air at $37^{\circ} \mathrm{C}$ for $24 \mathrm{~h}$.

\section{Evaluation of single-cell invasion: Working time 1 h for 6 condi-} tions

7) Focus an inverted phase-contrast microscope (with objective $10 x$ or 20x) downwards from the culture medium to the top of the gel onto a single focal plane. The edges of the cells appear brighter (cells have a 'halo' of light) compared to the background. The degree of reduction in brightness depends on the refractive index. Dense structures such as the nucleus or fibrillar collagen appear dark. Cellular extensions invading the collagen matrix appear dark because they are located out of phase (focal plane). Occasionally and dependent from cell-line to cell-line whole single-cells have migrated into the gel and appear dark.

CRITICAL: Choose the first field near the center of the well, consecutive fields are located randomly starting from this central field. Reject fields containing optical artefacts. Use microscope fields with a total of 20-25 cells.

TROUBLESHOOTING advice can be found in Table 2 .

8) Take a digital image from 10-15 microscope fields.

\section{Calculation of invasion index (manual cell counting): Working time $1 \mathrm{~h}$ for 6 conditions}

9) Calculate the invasion index (cells with invasive extensions versus total number of cells $\times 100$ ) by manual counting the number of invading and non-invading cells present in 10-15 microscope fields. Results can be plotted as depicted in Fig. 2 .

\section{Calculation of invasion area (digital analysis): Working time $3 \mathrm{~h}$} for 6 conditions

10) Process image into a binary image to allow computerized quantification of the invasive extensions. This implicates a two step process. Fig. 2 shows a raw binary image that includes invasive cellular extensions and binary artefacts such as collagen fibers and intracellular structures. Finally, logical subtraction allows to identify the invasive cellular extensions (Fig. 2). The mean invasion area from 10-15 microscopy fields can be calculated by counting the pixel number (Fig. 2).

\section{Evaluation of F-actin cytoskeleton organization: Working time} $2 h$ for 6 conditions

11) Fix collagen matrices for 20 min with $3 \%$ paraformaldehyde in PBS at room temperature.

TIMING: Fixed matrices can be kept in PBS at $4^{\circ} \mathrm{C}$ for 2 weeks.

12) Remove a $1 \mathrm{~cm}^{2}$ surface by scalpel and forceps from the middle of the collagen gel.

TROUBLESHOOTING advice can be found in Table 2 .

13) Permeabilize collagen gels for 15 min with $0.5 \%$ Triton $X$ 100 in PBS and block for 30 min with $2 \% B S A / 1 \%$ glycine in PBS (Denys et al., 2008). Incubate samples for $30 \mathrm{~min}$ at $37^{\circ} \mathrm{C}$ with Alexa Fluor 488 or 594 conjugated phalloidin, followed by extensive washing and mounting.

CRITICAL: Always keep samples in the dark when using fluor dye conjugated phalloidin. Solidify mounting medium on a cold plate.

Fix edges of cover glass with nailpolish to avoid movement during microscopy.

14) Cells are imaged by confocal laser-scanning microscopy using a 488 argon or a $543 \mathrm{HeNe}$ laser. Images are acquired using a Plan NeoFluar 40X/1 lens.

\section{Calculation of factor shape: Working time $1 \mathrm{~h}$ for 30 cells}

15) Process image into a binary image to allow computerized

TABLE 2

\section{TROUBLESHOOTING TABLE OF SINGLE CELL COLLAGEN INVASION MODEL}

\begin{tabular}{|c|c|c|c|}
\hline Step & Problem & Possible reason & Solution/action \\
\hline \multirow[t]{3}{*}{1} & $\begin{array}{l}\text { Formation of precipitate during mixing of } \\
\text { solutions }\end{array}$ & The mix is too alkaline & Reduce volume of $\mathrm{NaOH}$ \\
\hline & Air bubbles in solution & High pressure pipetting & $\begin{array}{l}\text { Pipet gently } \\
\text { Remove air bubbles by centrifugation and carefull aspiration of bubbles by pipetting }\end{array}$ \\
\hline & Polymerization of solution & High temperature & Keep solution on melting ice \\
\hline \multirow[t]{5}{*}{6} & $\begin{array}{l}\text { Inhomogeneous distribution of single cells } \\
\text { over collagen surface }\end{array}$ & Unefficient shaking & $\begin{array}{l}\text { Use left-right and forward-backward movements, do not use circular movements of 6-well plate } \\
\text { Check homogeneous distribution of cells by phase-contrast microscopy after cell seeding and shaking }\end{array}$ \\
\hline & $\begin{array}{l}\text { Cell doublets or islands instead of single } \\
\text { cells }\end{array}$ & Unefficient trypsinization procedure & $\begin{array}{l}\text { Optimize trypsinization procedure } \\
\text { Avoid cell doublets and clusters by filtering the cell suspensions through } 30-35 \mu \mathrm{m} \text { sterile meshes or fine } \\
\text { needle aspiration }\end{array}$ \\
\hline & Floating collagen gel & High pressure seeding of cells & Gently pipet single cell suspension along the side of the well plate on the collagen gel \\
\hline & & Plates were disturbed during incubation & $\begin{array}{l}\text { Never slam doors of the respective and adjacent incubators } \\
\text { If feasible, use separate incubator for incubation to elude frequent openings }\end{array}$ \\
\hline & Dissolved collagen gel & Use of hypertonic solutions & $\begin{array}{l}\text { Check osmolality of test products } \\
\text { Make test products isotonic }\end{array}$ \\
\hline \multirow[t]{5}{*}{8} & Impossibility to find superficial cells & $\begin{array}{l}\text { Highly invasive cells make it difficult to discern } \\
\text { the top of the collagen gel }\end{array}$ & Add carbon particles, they remain on top of the collagen gel and will not invade into the collagen \\
\hline & & Too many floating cells & $\begin{array}{l}\text { Remove floating cells } \\
\text { Check toxicity of test product }\end{array}$ \\
\hline & & $\begin{array}{l}\text { Superficial cells are deeper on one side of the } \\
\text { microscope field compared to the other side }\end{array}$ & $\begin{array}{l}\text { The surface of a gel is not always completely flat, choose therefore another field } \\
\text { Avoid cell counting at the periphery }(1 \mathrm{~cm}) \text { of the well, because here meniscus formation of the collagen } \\
\text { can disturb the top level of the gel, and can contain fewer cells due to rolling towards the more central } \\
\text { parts. }\end{array}$ \\
\hline & Presence of debris or small particles & $\begin{array}{l}\text { Small particles in standard medium and/or } \\
\text { serum }\end{array}$ & Monitor media and filter supplemented media through sterile filter if required \\
\hline & Dynamics of invasion & & $\begin{array}{l}\text { Perform time lapse video recordings using Axiovert 200M equipped with temperature controlled CO2- } \\
\text { incubation system }\end{array}$ \\
\hline \multirow[t]{2}{*}{13} & Destruction of collagen gel while cutting & Unefficient fixation & Fix $20 \mathrm{~min}, 3 \%$ paraformaldehyde at room temperature \\
\hline & & Clumsy cutting and forceps handling & Increase your handiness and experience on "try-out" collagen gels \\
\hline
\end{tabular}


quantification of perimeter and area of 30 imaged cells and calculate factor shape.

\section{Heterotypic spheroid collagen invasion model} For schematic see Fig. 3.

\section{Spheroid initiation: Working time $1 \mathrm{~h}$}

1) Prepare a single-cell suspension (see step 3 single-cell invasion model).

CRITICAL: Use cancer cells transfected with reporters such as GFP or DsRed for optimal contrast between cancer cell spheroid and collagen gel during image analysis.

2) To initiate compact spheroids of $150-\mu \mathrm{m}$ diameter at day 3 after inoculation, dilute dissociated cells to appropriate concentrations in $6 \mathrm{ml}$ standard medium, e.g. $2 \times 10^{5}$ cells $\mathrm{ml}^{-1}$ for HCT-8/E11-GFP human colon cancer cells, in a 50-ml Erlenmeyer flask. This cell number is sufficient to obtain $+/-100$ compact spheroids of $150-\mu \mathrm{m}$ diameter.

CRITICAL: For each cancer cell line, the cell number that is needed to create spheroids of $+/-150 \mu \mathrm{m}$ in diameter at day 3 after initiation has to be determined empirically (Friedrich et al., 2009). In our setup, compact spheroid formation is routinely checked by individual microscopic evaluation for cell concentrations ranging from $5 \times 10^{4}$ to $5 \times 10^{5}$ cells $\mathrm{ml}^{-1}$.

TROUBLESHOOTING advice can be found in Table 3.

3) Incubate Erlenmeyer flasks for $72 \mathrm{~h}$ on a Gyrotory shaker at $37^{\circ} \mathrm{C}$ and $70 \mathrm{rpm}$ in humidified atmosphere with $10 \% \mathrm{CO}_{2}$ in air.

TROUBLESHOOTING advice can be found in Table 3.

4) After $72 \mathrm{~h}$ of incubation (day 3 after initiation of spheroids) control sphericity and compaction of spheroids by individual microscopic monitoring ( $x-y-z$ direction).

If spheroids are spheric and compacted proceed with step 7. CRITICAL: Avoid precipitation and/or attachment of spheroids on glass substrate. Replace Erlenmeyer containing spheroids on a Gyrotory shaker at $37^{\circ} \mathrm{C}$ and $70 \mathrm{rpm}$ in humidified atmosphere with $10 \% \mathrm{CO}_{2}$ in air, when quality control is microscopically evaluated.

TROUBLESHOOTING advice can be found in Table 3.
Preparation of collagen type / bottom gellayer (eventually containing stromal cell population): Working time 30min, incubation time $1 \mathrm{~h}$

5) Prepare a single-cell suspension from primary myofibroblasts cultured in standard medium by mild enzymatic dissociation, using a $\mathrm{Ca}^{2+}$ - and $\mathrm{Mg}^{2+}$-free PBS wash followed by incubation with a trypsin/EDTA solution (usually $70 \%$ confluence is used).

\section{CRITICAL}

See step 3 single-cell collagen invasion model.

6) Prepare collagen type I solution (see step 1 of single-cell collagen invasion model).

7) Prepare $1 \times 10^{6}$ viable, single myofibroblasts in $1.25 \mathrm{ml}$ collagen type I solution and pour gently in a well of 6 -well plate. For control use $1.25 \mathrm{ml}$ of collagen type I solution without myofibroblasts.

CRITICAL: Use left-right and forward-backward movement of the 6-well plate to make sure the cells are evenly distributed in the whole gel solution.

8) Incubate collagen gels in a humidified atmosphere with $10 \% \mathrm{CO}_{2}$ in air at $37^{\circ} \mathrm{C}$ for $1 \mathrm{~h}$.

Preparation of spheroid-containing collagen type / gellayer: Working time $1 \mathrm{~h}$, incubation time $1 \mathrm{~h}$

Perform step 9-10 during gelification time of bottom collagen type I layer.

9) Transfer approximately 20 spheroids (a volume of $1.20 \mathrm{ml}$ ) in a $15 \mathrm{ml}$ polypropylene tube. Let the spheroids sediment through gravitation.

CRITICAL: Do not centrifuge spheroids, they may stick together to form one large aggregate.

10) Discard the supernatant and add $1.25 \mathrm{ml}$ of collagen type I solution. Mix gently, avoid the introduction of air bubbles and pour gently onto existing collagen type I layer.

CRITICAL: Avoid high shear stress by pipetting, it may damage-desintigrate the spheroids. Use left-right and forwardbackward movement of the 6-well plate to make sure the spheroids are evenly distributed in the whole gel solution. TROUBLESHOOTING advice can be found in Table 3.

TABLE 3

\section{TROUBLESHOOTING TABLE OF HETEROTYPIC SPHEROID COLLAGEN INVASION MODEL}

\begin{tabular}{|c|c|c|c|}
\hline Step & Problem & Possible reason & Solution/action \\
\hline \multirow[t]{6}{*}{$1-4$} & \multirow[t]{2}{*}{ Formation of irregular, noncircular spheroids } & $\begin{array}{l}\text { Use of cell suspension containing too many cell } \\
\text { clusters/doublets }\end{array}$ & $\begin{array}{l}\text { Optimize trypsinization procedure } \\
\text { Avoid cell doublets and clusters by filtering the cell suspensions through } 30-35 \mu \mathrm{m} \text { sterile } \\
\text { meshes or fine needle aspiration }\end{array}$ \\
\hline & & Small particles in medium and/or serum & $\begin{array}{l}\text { Check cleanness of beakers and of any other reusable glass or plastic materials } \\
\text { Monitor standard media and filter through sterile filter if required } \\
\text { Carefully aliquot heat-inactivated serum to omit solid particles }\end{array}$ \\
\hline & \multirow[t]{2}{*}{$\begin{array}{l}\text { Formation of loose cell aggregates of compact } \\
\text { spheroid-forming cell lines }\end{array}$} & $\begin{array}{l}\text { Disordered aggregation of cells either after thawing } \\
\text { or at high passages or due to mycoplasma } \\
\text { contamination }\end{array}$ & $\begin{array}{l}\text { Transfer stock solutions at least twice after thawing and before spheroid initiation } \\
\text { Trash morphologically altered cells and renew stock cultures from frozen backup } \\
\text { Check regularly for mycoplasma contamination, trash culture if positive }\end{array}$ \\
\hline & & Incorrect incubation conditions & Check incubator settings and $\mathrm{CO} 2$ connections \\
\hline & $\begin{array}{l}\text { No spheroid formation or formation of loose } \\
\text { cell aggregates }\end{array}$ & Non-compacting or non-aggregating cell line & $\begin{array}{l}\text { e.g., MDA-MB- } 231 \text { breast cancer cells do not form compact spheroid but loose cell } \\
\text { aggregates. This cell line is not suitable in the spheroid invasion assay }\end{array}$ \\
\hline & $\begin{array}{l}\text { Spheroids are attached to bottom of } \\
\text { Erlenmeyer }\end{array}$ & Shaking was disturbed & $\begin{array}{l}\text { Do not stop Gyrotory shaker during spheroid initiation } \\
\text { Be aware of power breaks during spheroid initiation }\end{array}$ \\
\hline \multirow[t]{2}{*}{$11-12$} & \multirow[t]{2}{*}{ Detachment of second layer from first layer } & $\begin{array}{l}\text { Incubation time for gelification of second collagen } \\
\text { layer was to short }\end{array}$ & Increase incubation time, at least $1 \mathrm{~h}$ \\
\hline & & $\begin{array}{l}\text { High pressure pipetting of standard medium on } \\
\text { second collagen layer }\end{array}$ & Pipet gently \\
\hline
\end{tabular}



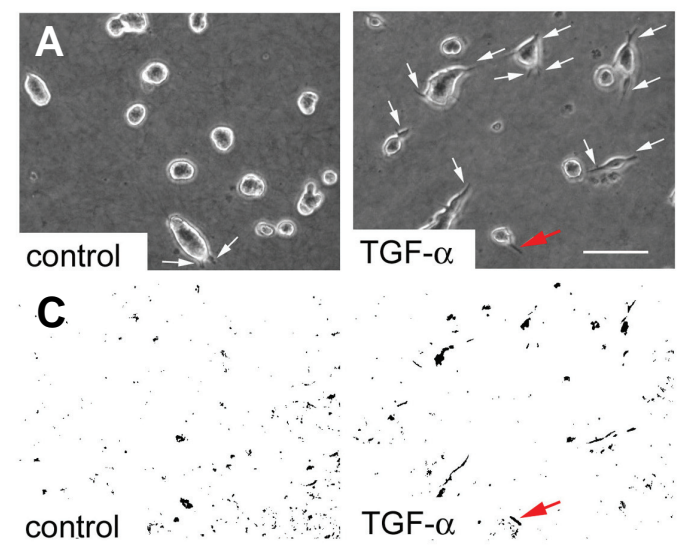

D

$r$

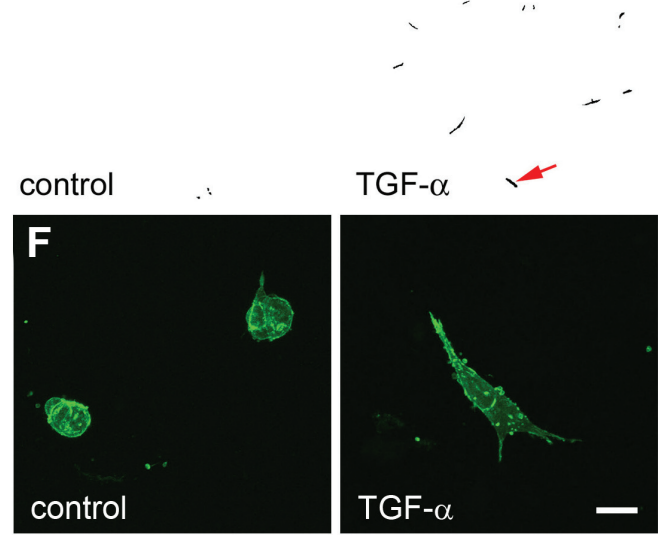

B

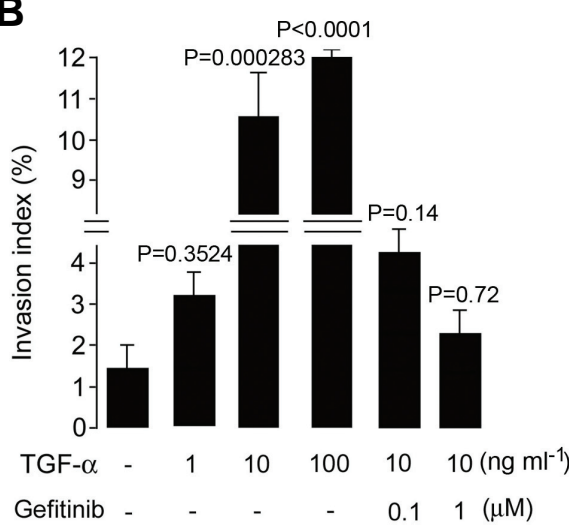

E

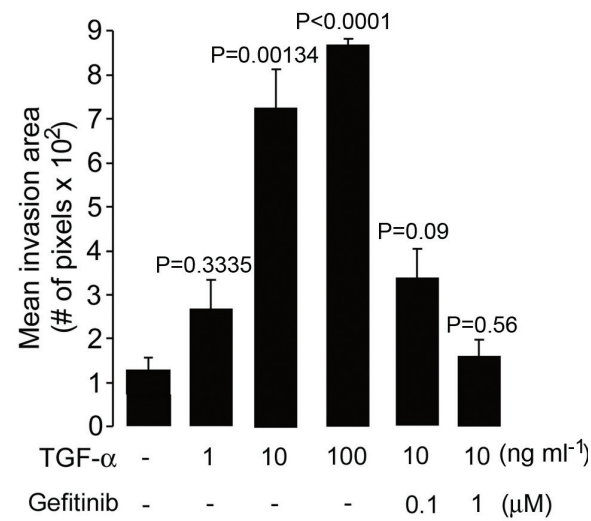

Fig. 2. Representative data of a single-cell collagen invasion assay. (A) Phase contrast pictures of single HCT-8/E11 colon cancer cells seeded on collagen type I gel and cultured for $24 \mathrm{~h}$ in culture medium or culture medium supplemented with TGF- $\alpha\left(10 \mathrm{ng} \mathrm{m}^{-1}\right)$. Arrows indicate invasive extensions. Scale bar, $20 \mu \mathrm{m}$. (B) Quantification of collagen invasion by calculating the invasion index which is the ratio of the number of cells containing invasive extensions over the total number of cells counted in each field, for a total of 10 fields. (C) Computerized binary image processing of phase contrast pictures. (D) Processed binary image by logical subtraction of artefacts such as dense collagen fibres and nuclei. In (A,C,D), the red arrow shows consecutive focusing of one invasive extension in phase contrast picture, unprocessed binary image and logical subtracted binary image. (E) Quantification of the invasion area by counting the number of pixels by computerized Image $J$ analysis. (F) Confocal images of representative phalloidinAlexa Fluor 488 stained HCT-8/E11 cells cultured for $24 \mathrm{~h}$ on collagen type I. Arrows indicate spreaded cells with formation of cellular extensions. Scale bar, $20 \mu \mathrm{m}$.

11) Incubate in a humidified atmosphere with $10 \% \mathrm{CO}_{2}$ in air at $37^{\circ} \mathrm{C}$ for $1 \mathrm{~h}$ to allow gelification of collagen solution. TROUBLESHOOTING advice can be found in Table 3 .

12) Code all individual spheroids by numbering them with a pen on the bottom of the well plate. Add $2 \mathrm{ml}$ of standard medium, refresh every $48 \mathrm{~h}$ and incubate in a humidified atmosphere with $10 \% \mathrm{CO}_{2}$ in air at $37^{\circ} \mathrm{C}$.

CRITICAL: Avoid high pressure addition (and exchange) of standard medium, it may damage the collagen gel.

Avoid aspiration of medium but gently remove medium by pipetting.

TROUBLESHOOTING advice can be found in Table 3.

Evaluation of spheroid invasion: Working time $1 \mathrm{~h}$ per condition, every day over a period of 4 days

13) Collect phase-contrast GFP images of all individual spheroids at start of incubation and every $24 \mathrm{~h}$ thereafter e.g.,

on a Zeiss Axiovert 200 with objective $10 x$ equipped with camera system.

Calculation of area, factor shape, and percentage fragmentation by digital analysis: Working time $1 \mathrm{~h}$ for $20 \mathrm{im}$ ages

14) Process phase-contrast GFP images into a binary image to allow computerized quantification. Analyse the number of pixels and calculate the mean area and perimeter of 20 spheroids by Image J (Fig. 4B and 4D). Calculate factor shape and percentage fragmentation (Fig. 4C).

\section{Evaluation of F-actin cytoskeleton or- ganization: Working time $1 \mathrm{~h}$ for 2 con- ditions}

See step 11-14 in single-cell collagen invasion model.

\section{Results and Discussion}

\section{Single-cell collagen invasion model}

Critical to the integration of the single-cell collagen invasion model into testing protocols of pro- or antiinvasive compounds is the selection of suitable cell lines. Therefore, 15 established, commercially available human cancer cell lines derived from different tumor types are characterized for their morphotype on tissue culture substrate and single-cell invasion into collagen type I (Table 1). For example, HCT-8/E11 cells seeded on top of collagen type I gels, mostly attach as round cells on the collagen with the appearance of a bright halo when cells are in phase (Fig. 2). Occasionally, formation of invasive cellular extensions with a dark appearance is observed. The single-cell invasion model is further validated by evaluating the impact of recombinant TGF- $\alpha$, a wellrecognized pro-invasive growth factor activating the EGF receptor (Rodrigues et al., 2003). As expected, HCT-8/E11 cells supplemented with TGF- $\alpha$ show a tremendous change in morphotype. When TGF- $\alpha$-treated HCT-8/E11 cells are in phase, multiple cells show a bright halo with dark, cellular extensions (Fig. 2) that are out of phase and actually located inside the collagen matrix. Treatment with TGF- $\alpha$ stimulates the invasive potential of HCT8/E11 cells in a dose-dependent manner (Chi Square test; $1 \mathrm{ng} \mathrm{ml}^{-}$ ${ }^{1}, \mathrm{P}=0.3524 ; 10 \mathrm{n} \mathrm{ml}^{-1}, \mathrm{P}=0.000283 ; 100 \mathrm{n} \mathrm{ml}^{-1}, \mathrm{P}<0.0001$ ) (Fig. 2). Accordingly, a clinically approved inhibitor of the EGF receptor, gefitinib, abrogates the TGF- $\alpha$-stimulated invasion in a dosedependent manner (Chi Square test; $10 \mathrm{ng} \mathrm{ml}^{-1}$ TGF- $\alpha$ combined with $0.1 \mu \mathrm{M}$ gefitinib, $\mathrm{P}=0.14$; $10 \mathrm{ng} \mathrm{ml}^{-1} \mathrm{TGF}-\alpha$ combined with 1 $\mu \mathrm{M}$ gefitinib, $\mathrm{P}=0.72$ ). Alternatively to manual cell counting, binary 
image processing allows computerized quantification of the invasive extensions (Fig. 2). The mean invasion area can be calculated by counting the pixel number of the dark-appearing cellular extensions (Fig. 2), which is significantly higher when HCT-8/E11 cells are supplemented with increasing concentrations of TGF- $\alpha$ (Mann Whitney test; $1 \mathrm{ng} \mathrm{ml}^{-1}, \mathrm{P}=0.3335 ; 10 \mathrm{ng} \mathrm{ml}^{-1}, \mathrm{P}=0.000134$; 100ng $\left.\mathrm{ml}^{-1}, \mathrm{P}<0.0001\right)$. As expected, gefitinib blocked TGF- $\alpha$ stimulated invasion (Mann Whitney test; $10 \mathrm{ng} \mathrm{ml}^{-1}$ TGF- $\alpha$ combined with $0.1 \mu \mathrm{M}$ gefitinib, $\mathrm{P}=0.09 ; 10 \mathrm{ng} \mathrm{m}^{-1} \mathrm{TGF}-\alpha$ combined with $1 \mu \mathrm{M}$ gefitinib, $\mathrm{P}=0.56)$. Cell viability check by Trypan blue exclusion at the end of the experiment showed that this inhibitor did not exert a toxic effect (not shown). The standard deviation of HCT-8/E11 single-cell invasion is reproducibly below $10 \%$ between different experiments. Subsequently, the effect of TGF- $\alpha$ on organisation of the $\mathrm{F}$-actin cytoskeleton is investigated on individual HCT-8/E11 cells (Fig. 2). Approximately 99\% of control cells have a rounded morphology with prominent cortical (associated with plasmamembrane) F-actin and membrane blebs. Addition of TGF- $\alpha$ disrupts the cortical F-actin in many cells and produces a more elongated cell morphology with multiple long protrusions. In agreement, the factor shape for control cells has a mean of $1.6+/-0.6$, indicating that they are generally rounded, whereas TGF- $\alpha$ treated cells have increased mean values of 5.9 +/- 1.3 (Mann Whitney test; $\mathrm{P}<0.0001$ ).

\section{Heterotypic spheroid collagen invasion model}

A possible disadvantage of the single-cell invasion assay is that it lacks structural architecture and that the cells are added under a mono-dispersed state. The multicellular spheroid system is much more adapted to study invasion mechanisms taking into account homotypic cell-cell contacts. The spheroid invasion model also reproduces some aspects of the restrictions in cellular growth and viability observed in growing tumors in vivo. Growing spheroids in vitro mimick growing tumors in vivo and their associated progressive deprivation in oxygen (hypoxia), nutrients, growth factors as

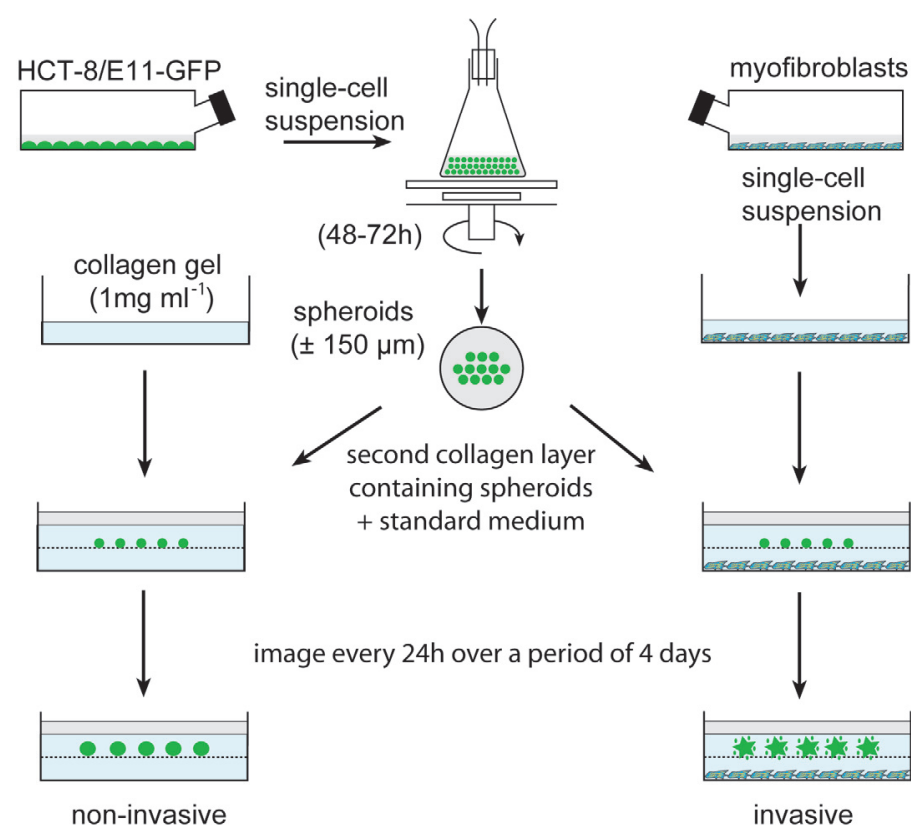

Fig. 3. Schematic of the heterotypic spheroid invasion model. well as limitations in the penetration and action of drugs. According to literature data, it is expected to identify drug candidates with less therapeutic efficacy in the heterotypic spheroid invasion model (Friedrich et al., 2009). Furthermore, a stromal-derived 50-gene signature predicts resistance to preoperative chemotherapy (5 fluorouracil, epirubicin, cyclophosphamide) in estrogen receptornegative breast cancer (Farmer et al., 2009). Here, co-culture spheroids will be a tool for negative selection and could (i) contribute significantly to a reduction in animal testings and thus to economical savings and (ii) also become a powerful model to optimize drug candidates for enhanced efficacy. Conversely, there is also experimental evidence that some drugs may exclusively be effective in three-dimensional but not two-dimensional culture, as has been seen in some target-specific treatment modalities, often with the molecular target being expressed only or particularly in a three-dimensional environment (Wang etal., 2002). The co-culture setup of colon cancer cells with colon tumor-derived myofibroblasts in the heterotypic spheroid invasion model allows for investigation of the intimate cellular and molecular cross-signaling between tumor-associated host cells and cancer cells. A representative phase contrast-GFP picture of one HCT-8/E11-GFP spheroid is shown at different time intervals (Fig. 4A). Under control conditions it is obvious that the cancer cell spheroid increases in volume over time but remains shaped as a compact spheric structure. In sharp contrast, the cancer cell spheroid in co-culture with human colon myofibroblasts has a robust increase in volume, is irregularly shaped at the surface circumference, and is fragmented. The cross-signaling with myofibroblasts induces an invasive growth program in HCT-8/E11 colon cancer cells. This invasive growth program (Fig. 4B) is characterized by the factor shape, the percent fragmentation and the mean area calculated from 20 spheroids at each time point. The factor shape has a mean value of $1.3+/-0.2$ at time $\mathrm{Oh}$ indicating the circularity. Under control conditions this value reaches a maximum mean value of $2.84+/-0.4$ at time $96 \mathrm{~h}$, still indicating that the spheroid shape is generally retained (Fig. $4 \mathrm{C}$ ). Under co-culture conditions this value reaches a maximum mean value of $9.41+/-0.85$ at time $96 \mathrm{~h}$ (Mann Whitney test; $\mathrm{P}=0.000347$ ), indicating the irregular, infiltrating shape of the spheroid. The percent fragmentation remains lower than $1 \%$ under control conditions and does not vary with time (Fig. 4C). However, starting after $48 \mathrm{~h}$ of heterotypic signalling with myofibroblasts, fragmentation is 3 -fold stimulated and this fragmentation remains persistent. The size of the patterned spheroid structure is calculated as mean area and is significantly higher starting $24 \mathrm{~h}$ after coculture with myofibroblasts as shown in Fig. 4D (repeated measures ANOVA test, $\mathrm{P}<0.001$ ).

Perhaps the most challenging aspect of complex co-culture studies is to define the phenotypic composition of the growing spheroids. Phenotyping with specific molecular markers, e.g., for cell-cell adhesion (E-cadherin), proliferation (Ki-67), apoptosis (TUNEL) and motility (F-actin), could be done by conventional immuno-histochemical methods on paraffin sections and 3D staining by confocal microscopy in order to connect phenotypes and their relative dominance with tumor morphology. Investigation of the F-actin organization by confocal microcopy reveals that the control spheroids are smoothly edged with occasional formation of invasive extensions (Fig. 4E). However, in the myofibroblast coculture the spheroid structure has a rough surface and shows fragmented cells inside the collagen matrix. This roughness re- 
A on
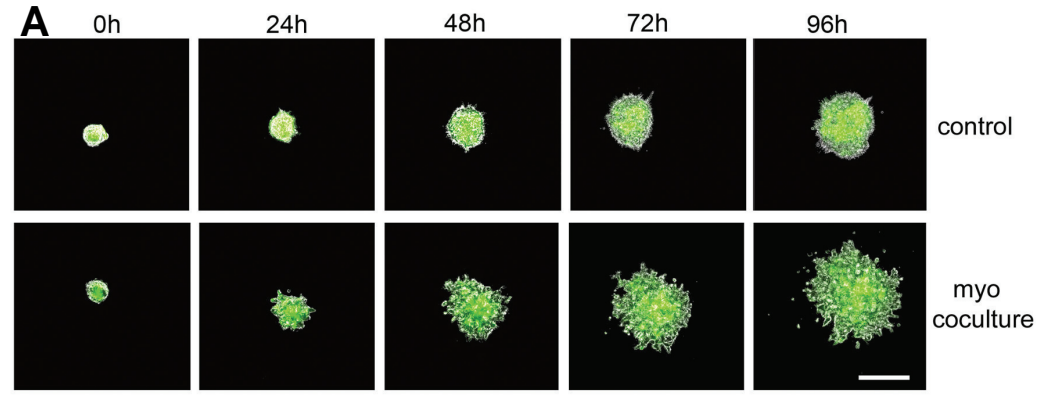

B on

?
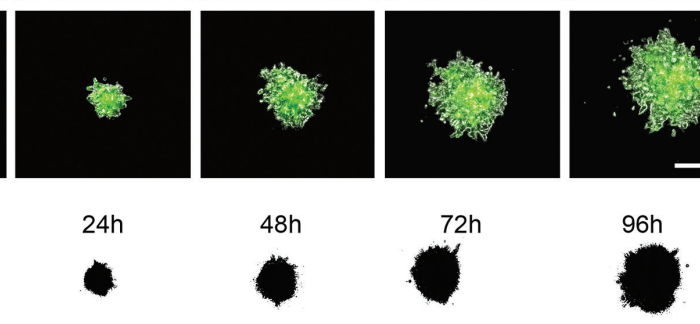

control
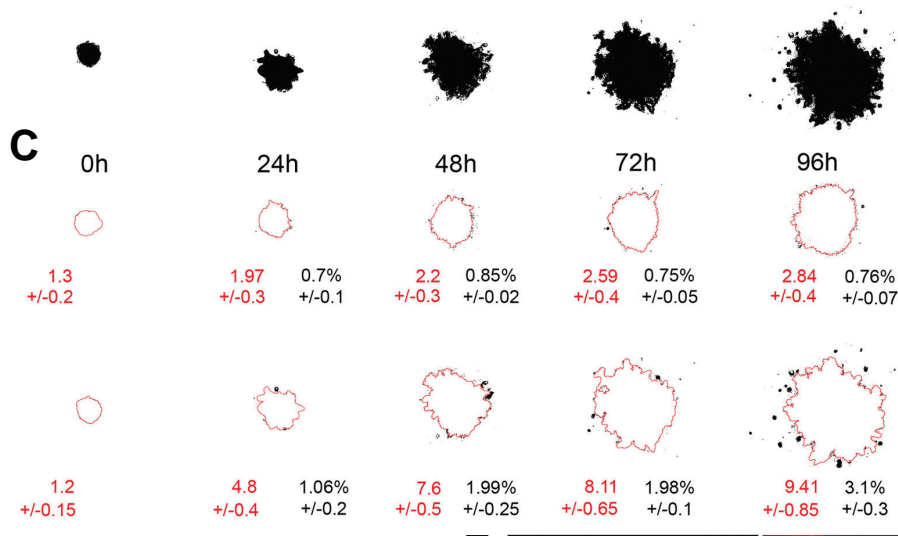

myo coculture
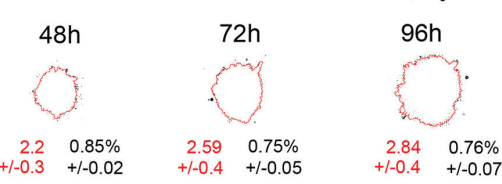

control
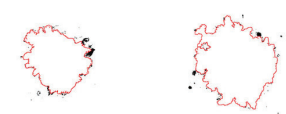

D
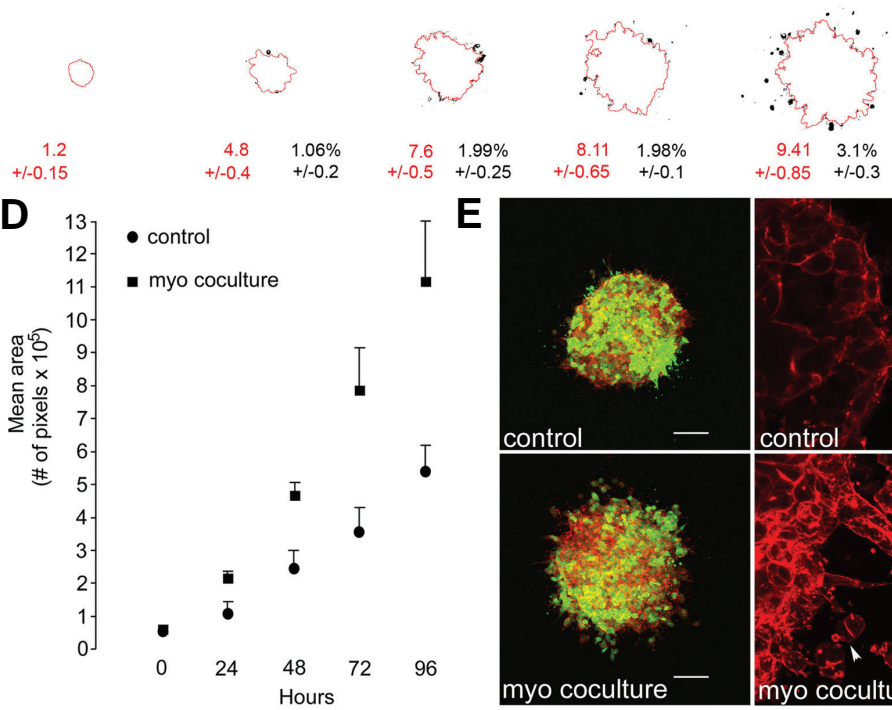

myo coculture flects invasive morphology and can be clearly appreciated by the confocal images of the F-actin staining.

In order to translate the findings from basic cellular research into clinical applications, cell-based models need to recapitulate both the three-dimensional organization and multicellular complexity of an organ but at the same time accommodate systematic experimental intervention. The invasion models, presented here, consist of native collagen type I containing nonhelical telopeptides situated at the $\mathrm{N}$ - and $\mathrm{C}$-terminal ends. These telopeptides play an important role in intermolecular covalent cross-links necessary for a gel architecture presenting itself as a structural barrier to cancer cell traffic (Sabeh et al., 2009). These systems allow (i) analysis of pro-/anti-invasive compounds, (ii) analysis of gene dosage/knock down on invasion, (iii) identification of specific mechanisms that underlie invasion, (iv) and analysis of the impact of the stromal environment on cancer invasion. Furthermore, the complementary assays are membrane-free and preserve cell morphology, allow real-time monitoring, have a kinetic flexibility and are highly reproducible. For example, in Transwe $\|{ }^{\circledR}$ chemoinvasion assays where cancer cells invade through a polycarbonate filter coated with a matrix substrate toward a chemoattractant, the number of cells crossing the filter can be counted at various time points. However, when invaded cells attach to the underside of the polycarbonate filter the possibility to perform morphotypic and morphometric analysis is greatly compromised. The collagen invasion models in combination with computerized quantification and powerful cell-pattern-recognition software are cost-effective and offer unprecedented potential for gaining new insights into cancer cell invasion. In support of this, a multiscale mathematical model of cancer invasion, which considers cellular and microenvironmental factors simultaneously and interactively, was developed to provide a theoretical and experimental framework to quantitatively characterize selective pressure for invasion (Anderson et al., 2006). The collagen invasion models, though not and exact replication of the in vivo environment, have many obvious applications especially in cancer research but also in tissue engineering and regenerative medicine (Narine et al., 2006).

\section{Acknowledgements}

M. Mareel is gratefully acknowledged for stimulating discussions. We thank Georges De Bruyne for excellent technical assistance. This work was funded by Fund for Scientific Research-Flanders (Komop Tegen Kanker-VLK:FWOAL455)(Brussels, Belgium), INSERM, ARC and the Scientific Exchange Program between the Flemish community and France (Grant 1.2007.03; T2009. 14). O. De Wever was supported by an EACR travelfellowship, and a post-doctoral grant from Fund for Scientific Research-Flanders. W. Westbroek was supported by the Intramural Research Program of the National Human Genome Research Institute.

\section{References}

conditions. The control spheroid is smoothly edged with occasionally the formation of an invasive protrusion. In the myofibroblast coculture the spheroid edge is fragmented with formation of invasive cells. The arrowhead shows fragmented cells extending short pseudopods inside the collagen matrix. The arrow shows an extension still attached with the main spheroid. Scale bars: left, $75 \mu \mathrm{m}$; right, $50 \mu \mathrm{m}$.
ALBINI, A. and BENELLI, R. (2007). The chemoinvasion assay: a method to assess tumor and endothelial cell invasion and its modulation. Nat Protoc 2: 504-511. 
ANDERSON, A.R.A., WEAVER, A.M., CUMMINGS, P.T. and QUARANTA, V. (2006). Tumor morphology and phenotypic evolution driven by selective pressure from the microenvironment. Cel/127: 905-915.

BEHRENS, J., VAKAET, L., FRIIS, R., WINTERHAGER, E., VAN ROY, F., MAREEL, M.M. and BIRCHMEIER, W. (1993). Loss of epithelial differentiation and gain of invasiveness correlates with tyrosine phosphorylation of the $E$ cadherin/ $\beta$-catenin complex in cells transformed with a temperature-sensitive $v$ src gene. J Cel/ Bio/120: 757-766.

BRUYÈRE, F., MELEN-LAMALLE, L., BLACHER, S., ROLAND, G., THIRY, M., MOONS, L., FRANKENNE, F., CARMELIET, P., ALITALO, K., LIBERT, C., SLEEMAN, J.P., FOIDART, J.-M. and NOËL, A. (2008). Modeling lymphangiogenesis in a three-dimensional culture system. Nat Methods 5: 431437.

DE WEVER, O., DERYCKE, L., HENDRIX, A., DE MEERLEER, G., GODEAU, F., DEPYPERE, H. and BRACKE, M. (2007). Soluble cadherins as cancer biomarkers. Clin Exp Metastasis 24: 685-697.

DE WEVER, O., NGUYEN, Q.-D., VAN HOORDE, L., BRACKE, M., BRUYNEEL, E., GESPACH, C. and MAREEL, M. (2004a). Tenascin-C and SF/HGF produced by myofibroblasts in vitro provide convergent pro-invasive signals to human colon cancer cells through RhoA and Rac. FASEB J18: 1016-1018.

DE WEVER, O., WESTBROEK, W., VERLOES, A., BLOEMEN, N., BRACKE, M., GESPACH, C., BRUYNEEL, E. and MAREEL, M. (2004b). Critical role of Ncadherin in myofibroblast invasion and migration in vitro stimulated by coloncancer-cell-derived TGF- $\beta$ or wounding. $J$ Cell Sci117: 4691-4703.

DENYS, H., DERYCKE, L., HENDRIX, A., WESTBROEK, W., GHELDOF, A., NARINE, K., PAUWELS, P., GESPACH, C., BRACKE, M. and DE WEVER, O. (2008). Differential impact of TGF- $\beta$ and EGF on fibroblast differentiation and invasion reciprocally promotes colon cancer cell invasion. Cancer Lett266: 263274.

FARMER, P., BONNEFOI, H., ANDERLE, P., CAMERON, D., WIRAPATI, P., BECETTE, V., ANDRÉ, S., PICCART, M., CAMPONE, M., BRAIN, E., MACGROGAN, G., PETIT, T., JASSEM, J., BIBEAU, F., BLOT, E., BOGAERTS, J., AGUET, M., BERGH, J., IGGO, R. and DELORENZI, M. (2009). A stromarelated gene signature predicts resistance to neoadjuvant chemotherapy in breast cancer. Nat Med 15: 68-74.

FINAK, G., BERTOS, N., PEPIN, F., SADEKOVA, S., SOULEIMANOVA, M., ZHAO, H., CHEN, H., OMEROGLU, G., METERISSIAN, S., OMEROGLU, A., HALLETT, M. and PARK, M. (2008). Stromal gene expression predicts clinical outcome in breast cancer. Nat Med 14: 518-527.

FRIEDRICH, J., SEIDEL, C., EBNER, R. and KUNZ-SCHUGHART, L.A. (2009). Spheroid-based drug screen: considerations and practical approach. NatProtoc 4: 309-324

FRITAH, A., SAUCIER, C., DE WEVER, O., BRACKE, M., BIÈCHE, I., LIDEREAU, R., GESPACH, C., DROUOT, S., REDEUILH, G. and SABBAH, M. (2008). Role of WISP-2/CCN5 in the maintenance of a differentiated and noninvasive phenotype in human breast cancer cells. Mo/ Cel/ Bio/28: 1114-1123.

GRIJELMO, C., RODRIGUE, C., SVRCEK, M., BRUYNEEL, E., HENDRIX, A., DE WEVER, O. and GESPACH, C. (2007). Proinvasive activity of BMP-7 through SMAD4/src-independent and ERK/Rac/JNK-dependent signaling pathways in colon cancer cells. Cel/ Signa/ 19: 1722-1732.

HANAHAN, D. and WEINBERG, R.A. (2000). The hallmarks of cancer. Cel/100:5770.

KEDESHIAN, P., STERNLICHT, M.D., NGUYEN, M., SHAO, Z.-M. and BARSKY S.H. (1998). Humatrix, a novel myoepithelial matrical gel with unique biochemical and biological properties. Cancer Lett 123: 215-226.

KUETTNER, K.E., PAULI, B.U. and SOBLE, L. (1978). Morphological studies on the resistance of cartilage to invasion by osteosarcoma cells in vitroand in vivo. Cancer Res 38: 277-287.

LIOTTA, L.A., LEE, C.W. and MORAKIS, D.J. (1980). New method for preparing large surfaces of intact human basement membrane for tumor invasion studies. Cancer Lett 11: 141-152.
MEERSCHAERT, K., BRUYNEEL, E., DE WEVER, O., VANLOO, B., BOUCHERIE, C., BRACKE, M., VANDEKERCKHOVE, J. and GETTEMANS, J. (2007). The tandem PDZ domains of syntenin promote cell invasion. Exp Cell Res 313: 1790-1804.

MOORADIAN, D.L., MCCARTHY, J.B., KOMANDURI, K.V. and FURCHT, L.T. (1992). Effects of transforming growth factor- $\beta 1$ on human pulmonary adenocarcinoma cell adhesion, motility, and invasion in vitro. J Nat/ Cancer Inst 84 523-527.

NARINE, K, DE WEVER, O., VAN VALCKENBORGH, D., FRANCOIS, K., BRACKE, M., DESMET, S., MAREEL, M. and VAN NOOTEN, G. (2006). Growth factor modulation of fibroblast proliferation, differentiation, and invasion: implications for tissue valve engineering. Tissue Eng 12: 2707-2716.

NGUYEN, Q.-D., DE WEVER, O., BRUYNEEL, E., HENDRIX, A., XIE, W.-Z., LOMBET, A., LEIBL, M., MAREEL, M., GIESELER, F., BRACKE, M. and GESPACH, C. (2005). Commutators of PAR-1 signaling in cancer cell invasion reveal an essential role of the Rho-Rho kinase axis and tumor microenvironment. Oncogene 24: 8240-8251.

NYSTRÖM, M.L., THOMAS, G.J., STONE, M., MACKENZIE, I.C., HART, I.R. and MARSHALL, J.F. (2005). Development of a quantitative method to analyse tumour cell invasion in organotypic culture. J Patho/205: 468-475.

PAULI, B.U., MEMOLI, V.A. and KUETTNER, K.E. (1981). In vitro determination of tumor invasiveness using extracted hyaline cartilage. Cancer Res 41: 20842091

PINNER, S. and SAHAI, E. (2008). PDK1 regulates cancer cell motility by antagonising inhibition of ROCK1 by RhoE. Nat Cell Bio/10: 127-137.

RODRIGUES, S., VAN AKEN, E., VAN BOCXLAER, S., ATTOUB, S., NGUYEN Q.-D., BRUYNEEL, E., WESTLEY, B.R., MAY, F.E.B., THIM, L., MAREEL, M., GESPACH, C. and EMAMI, S. (2003). Trefoil peptides as proangiogenic factors in vivoand in vitro: implication of cyclooxygenase-2 and EGF receptor signaling. FASEB J 17: 7-16.

ROPERCH, J.-P., EL OUADRANI, K., HENDRIX, A., EMAMI, S., DE WEVER, O., MELINO, G. and GESPACH, C. (2008). Netrin-1 induces apoptosis in human cervical tumor cells via the TAp73 $\alpha$ tumor suppressor. Cancer Res 68: 8231. 8239.

SABEH, F., SHIMIZU-HIROTA, R. and WEISS, S.J. (2009). Protease-dependent versus -independent cancer cell invasion programs: three-dimensional amoeboid movement revisited. J Cel/ Biol 185: 11-19.

VAKAET, L. Jr, VLEMINCKX, K., VAN ROY, F. and MAREEL, M. (1991). Numerical evaluation of the invasion of closely related cell lines into collagen type I gels. Invasion Metastasis 11: 249-260.

VAN AKEN, E.H., DE WEVER, O., VAN HOORDE, L., BRUYNEEL, E., DE LAEY, J.-J. and MAREEL, M.M. (2003). Invasion of retinal pigment epithelial cells: Ncadherin, hepatocyte growth factor, and focal adhesion kinase. Invest Ophthalmol Vis Sci 44: 463-472.

VERMEULEN, S.J., BRUYNEEL, E.A., BRACKE, M.E., DE BRUYNE, G.K., VENNEKENS, K.M., VLEMINCKX, K.L., BERX, G.J., VAN ROY, F.M. and MAREEL, M.M. (1995). Transition from the noninvasive to the invasive phenotype and loss of $\alpha$-catenin in human colon cancer cells. Cancer Res 55: 47224728.

VLEMINCKX, K., VAKAET, L. Jr, MAREEL, M., FIERS, W. and VAN ROY, F. (1991). Genetic manipulation of E-cadherin expression by epithelial tumor cells reveals an invasion suppressor role. Ce//66: 107-119.

WANG, F., HANSEN, R.K., RADISKY, D., YONEDA, T., BARCELLOS-HOFF, M.H., PETERSEN, O.W., TURLEY, E.A. and BISSELL, M.J. (2002). Phenotypic reversion or death of cancer cells by altering signaling pathways in threedimensional contexts. J Nat/ Cancer Inst 94: 1494-1503.

WOLF, K., MAZO, I., LEUNG, H., ENGELKE, K., VONANDRIAN, U.H., DERYUGINA E.I., STRONGIN, A.Y., BRÖCKER, E.-B. and FRIEDL, P. (2003). Compensation mechanism in tumor cell migration: mesenchymal-amoeboid transition after blocking of pericellular proteolysis. J Ce/l Bio/160: 267-277. 
Further Related Reading, published previously in the Int. J. Dev. Biol.

See Special Issue Pattern Formation edited by Michael K. Richardson and ChengMing Chuong at:

http://www.ijdb.ehu.es/web/contents.php?vol=53\&issue =5-6

Parallels in invasion and angiogenesis provide pivotal points for therapeutic intervention

Suzanne A. Eccles

Int. J. Dev. Biol. (2004) 48: 583-598

The "chemoinvasion assay": a tool to study tumor and endothelial cell invasion of basement membranes

Adriana Albini, Roberto Benelli, Douglas M. Noonan and Claudio Brigati

Int. J. Dev. Biol. (2004) 48: 563-571

Germinal tumor invasion and the role of the testicular stroma

Alejandro Díez-Torre, Unai Silván, Olivier De Wever, Erik Bruyneel, Marc Mareel and Juan Aréchaga

Int. J. Dev. Biol. (2004) 48: 545-557

The countercurrent principle in invasion and metastasis of cancer cells. Recent insights on the roles of chemokines

Ghislain Opdenakker and Jo Van Damme

Int. J. Dev. Biol. (2004) 48: 519-527

The stroma reaction myofibroblast: a key player in the control of tumor cell behavior

Alexis Desmoulière, Christelle Guyot and Giulio Gabbiani

Int. J. Dev. Biol. (2004) 48: 509-517

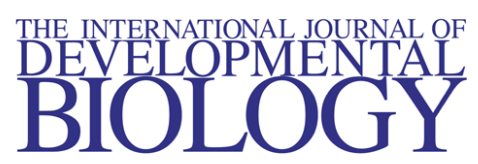

Volume 48 Nos. 5/6

Special issue

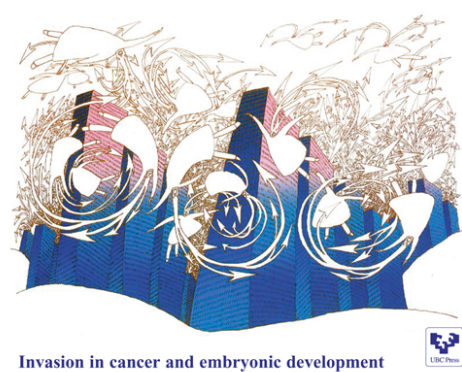

5 yr ISI Impact Factor (2008) = 3.271

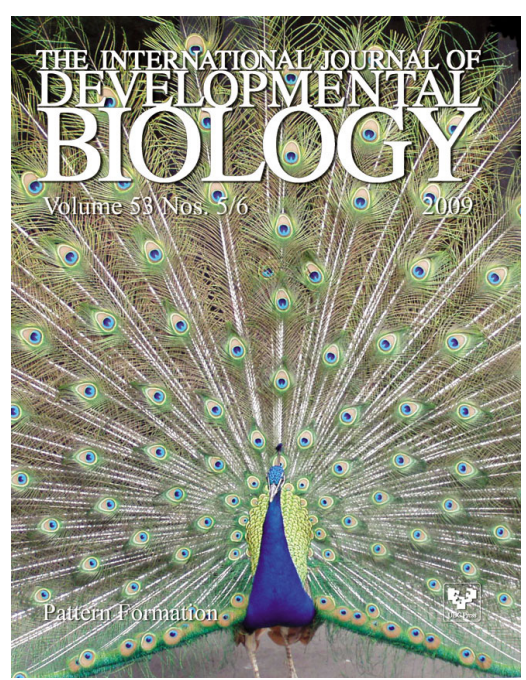

